\title{
Recent Research in Black Sea Region on Motivation in Education (Review)
}

\author{
Natela DOGHONADZE* \\ Iryna FEDORCHUK ${ }^{*}$
}

\begin{abstract}
Motivation in education - that of administrators, teachers and especially students - has always been one of essential preconditions of efficient learning and teaching. By itself it does not guarantee achievement, especially measures by testing and grades, but it created a good background for efficient learning. And vice versa, lack of motivation usually has a negative impact of achievement. Various aspects of motivation have been researched, and the topic seems eternal and inexhaustible. This review presents some research that has been recently held in the Black Sea region countries concerning motivation in education.
\end{abstract}

\section{Research in Georgia}

Gogokhia (2012: 24) in her PhD dissertation mentions that there exist certain myths concerning motivation. They are:

1) If students do not participate in classroom activities, they are not motivated;

2) A failure is a good motive to study better;

3) Learning is more important than motivation;

4) Teachers create students' motivation;

5) By threatening a teacher may create motivation;

\footnotetext{
* Prof. Dr., International Black Sea University, Tbilisi, Georgia.

E-mail: nateladoghonadze@ibsu.edu.ge

* PhD, Nizhyn Mykola Gogol State University, Nizhyn, Ukraine.

E-mail: irynafedorchuk@gmail.com
} 
6) Motivation automatically increases learning outcomes.

She criticizes the ideas as follows:

1) Student may not have learning motivation, but have some other motivation; this will cause disciplinary problems;

2) For some students failure is a good motive to study better, but repeated failure causes a lot of problems;

3) Though schools are focused on the content-matter, without seeing a practical goal in the course, learning becomes meaningless;

4) Teacher only helps students create internal motivation.

5) Negative emotions decrease motivation;

6) Motivation may decrease if lessons are poorly planned, assessment is unfair, etc.

In her research (ibid: 55) it was found that statistically motivation of learning English as a foreign language at Ilia State University (Georgia) was increasing significantly every year during the three years (2008-2011) under study:

- integrative for high-achieving students from 4.4 to 6.16 points in an 8-point scale;

- integrative for low-achieving students from 4.5 to 5.9 points;

- instrumental for high-achieving students from 5.6 to 6.0 points;

- instrumental for low-achieving students from 5.6 to 6.45 points.

Integrative motivation grew faster among successful students (probably, they were stimulated by the perspective of going to study or work abroad), while among less successful students' motivation instrumental motivation increased more. This, according to the researcher, reflects the social conditions in Georgia, where foreign languages, especially English, are attached a great practical meaning.

Kvirikashvili and Gogochashvili (2013) held a survey in one of Georgian schools with 150 students, 200 parents and 30 teachers concerning student motivation. It was found that $73 \%$ of the respondents believed that student motivation is lower with students coming from low socio-economic status (SES), and higher with high SES students. However, teachers' role is still great, they need to know the strategies that help increase students' motivation, so, as conclusion, the authors mention that schools should 
motivate teachers more though offering more possibilities of professional development as well as increasing salaries. School administration should also think about raising the collective self-efficacy of the school. Kvirikashvili and Gogochashvili (2013) held an action research in their school, applying needs-analysis-based school management increase not only teachers', but also students' motivation. The success rate of students in three years increased by $6 \%$ (of low-SES students - by $23 \%$ ), $70 \%$ of teachers were certified by the national examinations, and $4 \%$ became expert teachers.

Giorgadze, Gogrichiani, \& Mdinaradze (2014) studied the motivation of learning chemistry and related activities in order to improve the quality of teaching chemistry in a magnet school for students gifted in physics and mathematics. The results showed that the application of methods dealing with discovery increased students' motivation, while not using educational technologies for teaching decreases students' motivation. Teacher's personality also had an impact on students' motivation.

In Doghonadze (2012a) article it is underlined that teacher motivation and teacher job satisfaction are not synonyms, although they are often used synonymously. While job satisfaction simply deals with positive feelings in connection with one's job and may not include the desire to work better (however, the opposite may be true: dissatisfaction will most probably lead to demotivation to work better), job motivation is the driving force that moves a teacher work well. While no direct correlation between teacher motivation and student achievement (Stewens and White, 1987) (as well as between student motivation and student achievement) has yet been established, the correlation between teacher motivation and student self-esteem has been shown by Peck, Fox, and Morston (1977). It is mentioned that tertiary students' motivation is usually higher than secondary students, as tertiary education is chosen voluntarily, while secondary education is compulsory. 35 lecturers (8 from the UK, 14 - from Turkey and 13 - from Georgia) participated in the research, which showed a high enough university student motivation in all samples (mean results were from 4.23 to 4.5 in a five-point Likert scale), university student motivation should be still higher.

However, in another paper by Doghonadze (2012b) allegedly high motivation of undergraduate students is discussed. 95 students, including international ones - from Turkey, Azerbaijan, Tajikistan and Nigeria from International Black Sea Universities (all faculties) participated in the research. The conclusions list reasons, according to the research, why many young adults choose to continue studies and their majors without really being motivated (parents' pressure, peer impact, moratorium stage of development, performance goals vs. mastery goals, etc.). It is stated that both lecturers and students 
can and have to contribute to motivation increase, as one of the main factors of academic success is motivation. Ways to increase motivation are viewed, such as (on the lecturer's part) creating at university in general and in the particular classrooms a pleasant atmosphere of trust in students' abilities, creativity, achievement, doing everything to increase students' self-esteem, being caring, enthusiastic, objective, selection of usable and necessary, at the same time exciting topics and educational materials clear presentation/explanation, good audio-video materials, good examples, interactive lecturing, providing student involvement in planning and fulfillment of the educational process, development of student creativity, etc. and (on the students' part) active learning, perceiving themselves as knowledge creators or at least co-creators, taking more responsibility over one's learning, observing themselves and finding efficient for them learning style, methods and strategies, regular self-assessment, being more selfcritical and self-demanding, trying to study for knowledge, not for grades, etc.

\section{Research in Romania}

Necsoi (2013) studied Romanian students' motivation of study abroad. 50 last year school students were asked questions concerning the issue. She found that students are very motivated to study abroad, especially in Italy, France, UK, Germany, Denmark and Netherlands, and choose the country according to education conditions (equipment, teachers' qualification, students' opportunities to be involved in research and resources for their projects), employment opportunities, tuition language and culture of the country.

Serbanescu (2013) studied the relationship between the motivation to attend the teacher education programme and the acquisition of professional competences. The opinions of inspectors (40 respondents) responsible for lifelong training and those of the training programs' beneficiaries (569 respondents) throughout the whole country were investigated. The hypothesis of the research was that the students' level of involvement in their training for the teaching career is in an interdependence relationship with their motivation for completing the teacher education module. The motivations for choosing the pedagogical-psychological module in the program were:

- The courses are relatively easy to complete (76.1\%);

- I consider it as a second, back-up qualification (67.8\%);

- It gives me supplementary competences for my personal development (61.5\%);

- I want to pursue the teaching career (51.8\%); 
- The grade obtained may improve the annual grade point average (51.8) (ibid, p. 772).

The fact that only $51.8 \%$ of respondent students were planning to become teachers (however, life shows that those who take the courses "just in case" very often work as teachers) is very unpleasant - it, in fact, reveals (not only Romanian reality) that there are people who work as teachers, but this is not their vocation. Definitely, these teachers will never make motivated or good ones. The only inspiring answer is "it gives me supplementary competences for my personal development" with $61.5 \%$ of the respondents supporting the idea. Luckily, the majority of those who chose to become teachers did it for an altruistic, good for students reason:

- I like working with students (5.10 points - unfortunately, it is not clear out of how many);

- I have the necessary skills (4.78);

- The teacher mission is socially important (4.68);

- It is a safe job (3.80 - the only egoistic answer, but with quite a low rating);

- I come back as a teacher in the community (3.74) (ibid, 773).

\section{Research in Russia}

Elliott \& Tudge (2012) have studied the relationship between motivation for academic achievement and student engagement. They mention that motivation for academic achievement is often viewed as an individual characteristic. Students often do not see any difference between achievement motivation (i.e., how much they state that they are eager to work hard to achieve educationally) and engagement (i.e. student behaviour). Engagement really is a material proof of being motivated. According to Bronfenbrenner (2005; Bronfenbrenner \& Morris, 1998; 2006), spatial (culture) and temporal (historical time) context also matters in how motivation is expressed. The research is based on observations held in St. Petersburg (Russia) and Eastern Kentucky (USA) during the 1990s. The Russian students appeared considerably more interested in, and enthused by, academic activities, worked harder (both in class and on homework), and, unsurprisingly, generally achieved at a much higher level than those in Kentucky. Such engagement was especially surprising, taking into consideration Russia's substantial social and economic problems during the mid-1990s and the lack of direct connection between educational level and financial well-being. Student, teacher, and parent questionnaires and interviews were held. Self-reported data were collected about students' personal characteristics (their attitudes and values), their parents' beliefs and their teachers' perceptions, expectations and demands. 1,324 
Russian and 633 American 14- to 15-year-old students in high schools were involved in the first study, 877 Russian and 931 American 10-year-olds - in the second study and 1,389 Russian parents and 505 American parents). Also 36 teachers from both countries participated. The researchers examined aspects of the relevant cultural context, considering historical influences and traditions in each culture. Russian children emphasized that their peers stimulated them to behave in a way their teachers would expect them to. Among American children effortless success (due to giftedness) was more valued by peers than success due to effort. Many boys wanted to be treated as 'cool' by not learning well. Education (school certificate) for them was an instrument for continuing education and/or employment rather than a means of personal development. Family and community did not give them much support concerning their engagement in studies. Russian students, vice versa cared about personal development and were supported in it by family and society.

Concerning the temporal context, in Kentucky, contemporary views of education and academic achievement motivation are still influenced by the state's early history when too much education, in fact, was viewed as an expensive luxury and dangerous. In Russia after the 1917 revolution the education system largely maintained the previous quality and even increased it (Fitzpatrick, 1999; Holmes, 2005). The dramatic social and economic changes connected with the collapse of the USSR increased the globalization impacts, including the instrumental view of education. However, the old traditions were still strong enough.

Goncharov, A. M. McGinlay (2014) studied some motivational aspects of students, learning English as a second language in Russian technical universities. A trial survey was conducted at the Siberian State Aerospace University. It brought forward four key areas affecting the students' motivation which are within the teacher's ability to influence: the student's confidence in using the target language in the classroom; the use of the target language in the classroom by teachers; the class composition (in terms of the diverse levels of knowledge of the target language) often present in one group; and the broad impact of resources in contributing to the weariness of students to learn. Of the list, the most prominent was the students' level of confidence in their ability to use the target language in the class environment. Shklyaev (2013) describes three levels of higher educational institution academics' motivation:

I. The prestige of the profession, possibility of doing scientific research besides teaching, cognitive interest in the courses taught, and self-actualization. 
II. Pedagogical inclinations, the intellectual character of labour, the desire to share one's knowledge.

III. Pleasure derived from communication with students and colleagues, creativity, less emphasis on the role of material stimuli.

Although salary is not among the major factors of motivation, keeping in mind that it is necessary to maintain a sufficient number of university teachers as well as the quality of their work, this factor still has to be taken into consideration.

Bogoslovskaya (2006) cites sociological researches held by Russian mass-media which show that there are three motivation models of choosing to study at a higher education institution:

1) Having a diploma of higher education is a value in itself (35\% or the respondents), whether it is characterized by instrumental motivation (getting knowledge and employment) or not, e.g., procrastinating joining the army)

2) Circumstances, such as existence of a higher education institution where the young person resides, financial possibilities of the family, level of knowledge acquired at school (60-70\% of the respondents). Gender factor also plays a role: young females more often choose to study than males. Young males care more about the status gained via education, while females about income.

3) Refusal to study, due to having fun as a priority.

$36 \%$ of the respondents care about the prestige of the university and the quality of tuition, paying less attention to the international rating of the university as well as its popularity among employers, which reveals that they are more intrinsically than extrinsically motivated. This is confirmed by the answers that the interest towards profession (69\% of the respondents) is more important than the potential income (14\%).

\section{Research in Turkey}

Semerci \& Duman (2013) aimed at measuring achievement motivations of the students of Computer and Instructional Technologies Teaching (CITT) Department in two Turkish universities. 142 students were involved in a survey. Statements were given to students to be assessed in a 5-point scale. They cite Atkinson (1974: 207) in defining achievement motivation as "a tendency to strive for success in 
Journal of Education in Black Sea Region

ISSN: 2346-8246, Vol. 1, Issue 2, 2016

situations involving an evaluation of one's performance in relation to some standard of excellence". Achievement motivation involves intrinsic and extrinsic factors. External factors were found to be the highest (mean 3.89 and 4.13, according to the participating universities) in the given sample. However, intrinsic motivation was found high enough, too (3.52 and 3.67) (Semerci \& Duman, 2013: 138). This once more proves that we cannot expect all students to be intrinsically motivated and should apply extrinsic motivation effectively even in higher education.

Cetin (2015) tried to determine whether there is any impact of approaches to learning and academic motivation together on the university pre-school and primary school specialty students' grade point averages (GPA) in Turkey and USA. 166 participants from the USA and 455 from Turkey were involved in the study (one university in each country). Deep and surface approaches in the article are viewed based on Marton and Saljo (1976). Deci and Ryan (2002) are referred to in dealing with three categories: amotivation, extrinsic motivation, and intrinsic motivation. Face-to-face structured interviews with students were held to assess their motivation, while for defining GPA students' self-reports were used. In both samples participants' GPAs did not significantly correlate with academic motivation and approaches to learning. On the other hand, there was a significant correlation between academic motivation and approaches to learning (intrinsically motivated students more often applied deep approach, while extrinsically motivated students more often applied surface approach). However, the author admits that many other researches have found either a strong (Amrai et al, 2011; Özder \& Motorcan, 2013; Lavender, 2005) or a weak (Heikkila and Lonka, 2006) positive correlation between both the extrinsic and intrinsic motivation and the academic achievement. Cockley et al. (2001) found significant negative correlations between GPA and amotivation. Robinson (2003) detected a positive correlation between intrinsic motivation to achieve and achievement and a negative correlation between amotivation and achievement. Besides, Cetin mentions that many researches confirm the negative correlation between academic achievement and surface approach (Diseth (2002) and academic achievement and deep approach (Diseth, 2007; Ekinci, 2009). He explains the difference between his research and other studies by a large number of uncontrolled factors that possibly affect GPA: intelligence, age, educational level of parents, self-efficacy, learning styles and cognitive skills.

Aydin (2015) study aimed to analyze the relationship between high school students' self-efficacy perceptions regarding biology, the metacognitive strategies they use in this course and their academic motivation for learning biology $(r=.588, p<.01)$. The participants were 286 high school students enrolled in three high schools in Turkey. The use of high level metacognitive strategies was found highly enough 
Journal of Education in Black Sea Region

ISSN: 2346-8246, Vol. 1, Issue 2, 2016

correlated with students' intrinsic motivation $(r=.480, p<.01)$. A negative correlation was found between self-efficacy and amotivation, self-efficacy and extrinsic motivation.

The goal of Ates \& Saylan (2015) research was to assess pre-service science teachers' academic motivation and academic self-efficacy toward biology. The sample consisted of 369 pre-service science teachers from two universities in Turkey. The findings revealed that the respondents' academic selfefficacy ( 0.88 out of 1 maximum) and academic motivation toward biology (0.73) were high enough. Intrinsic motivation (4.80, according to a 5-point scale) was higher than extrinsic motivation (3.37), however, both of them are high enough. The correlation between intrinsic motivation and selfconfidence was found strong $(r=.68)$. The positive correlation between comprehension and biology experiment was the strongest $(r=.84)$, while between comprehension and problem solving (.821) and between problem solving and biology experiment (0.832) was also quite strong.

Izmirli \& Izmili (2015) research aimed at finding out the factors motivating pre-service teachers for online learning within the context of ARCS motivation model. 52 pre-service teachers from one university in Turkey participated. They had both theoretical knowledge of online learning models and benefits and corresponding practical experience. Four major factors of ARCS model were defined, with sub-factors each: attention (flexibility, multiple channel of material presentation, source variety, and interaction), relevance (to individual differences, of instant feedback, and flexibility), confidence (individual differences, progress under expert control, safety, resilience to the pressure of the environment), and satisfaction (instant feedback and time-saving).

\section{Research in Ukraine}

The research held by Kolosovska (2014) during 2008-13 aimed at studying the motivational component of pre-service primary school teachers' readiness to implement student-oriented approach in sports activities with pupils. The experimental group consisted of 84 participants and the control group - of 77 students of Bila Tserkva Humanitarian and Pedagogical College and Bohuslav Nechyi-Levytskyi Humanitarian College. The study was to determine the impact of information network for common creativity of university teachers and students on the students' motivation and readiness to implement student-oriented approach in practice. The author used the method "Disclosure, directivity evaluation and the level of motivation for studying" elaborated by Dubovitskaia (2005). At the beginning of research, the students of both groups had more or less the same level of motivation - the high level (control group - 7.79\%; experimental group - 10.71\%), medium (respectively $46.75 \%$ and $55.97 \%$ ) and 
low level (45.45\% and 33.33\%). At the final stage of the study, the results changed. The number of students with the high level of motivational readiness to implementation of student-oriented approach in control group raised up to $12.99 \%$ and to $21.43 \%$ in experimental group. The number of participants with the medium level also raised up to $50.65 \%$ (in control group) and to $70.24 \%$ (in experimental group). The same was for the students with the low level of motivation - 36.36\% (in control group) and 8.33\% (in experimental group). The dynamics proved the positive effect of information network for common creativity of university teachers and students on pre-service primary school teachers' readiness to implement student-oriented approach in practice.

Fedorchuk (2008) studied students' academic motivation for English for Specific Purposes (ESP) at Chernihiv State Institute of Economics and Management. The students of Law Department and Management Department were involved in the survey. 150 participants were second and third year students of full time department. The research duration was one year and it used different research techniques (observation, questionnaires, interviews with students, and study of students' academic achievements). The author states that motives are the inner driving force of studying and determine the academic achievement in ESP acquisition. The survey revealed that students had quite a strong motivation for ESP acquisition that was mainly dependent upon the clear vision of its practical use. The scope of the research included the study of students' wishes to increase the number of credits allocated for the discipline, individual work and students' considerations upon the most important language activity (writing, reading, listening and speaking). Among the main findings of the survey were the considerable part of students' motivations took the motives of social prestige $(70 \%)$, a group of students had utility motives (good performance along with a low interest to ESP and strong realization that it counts for general academic achievement), obligation feeling to studying ESP (5\%). The motivation complex included such motives as professional value motives (90\%) and educational motives (10\%).

Studying the ways for university language teachers' professional development, Moskalets \& Ponomarenko (2015) believe that a close study of students' motivation for L2 acquisition can be helpful in finding the individual track for each teacher to develop one's own professional competence. The participants of the survey were 110 first and second year students from Nizhyn Mykola Gogol State University. To study students' motivation for $\mathrm{L} 2$ acquisition a special questionnaire had been developed. It was based on the classification of teachers' motivational strategies and corresponding techniques. The authors cite Dörnyei (2001) who states that motivation strategies include creating the basic motivational conditions; generating initial motivation; protecting motivation and encouraging positive 
retrospective self-evaluation. And corresponding techniques imply appropriate teacher behaviors and a good relationship with the students; a pleasant and supportive classroom atmosphere; presenting tasks in a motivating way; setting specific learner goals; creating learner autonomy; providing motivational feedback; offering grades in a motivating way, etc. (Dörnyei, 2001). The 22 statements of the questionnaire represented 20 motivating and 2 demotivating techniques. E.g.: Your teacher is interested in your success. Your teacher notices and encourages your efforts at learning the language. Your teacher demonstrated who in their opinion is a good or a bad student. The students were asked to decide how often (never, sometimes, usually or always) their teacher used each technique in class. They also analyzed the techniques used by their nine university English teachers (two of the teachers were the authors of this survey). The results of the survey revealed that some teachers were better at using one set of motivational techniques while others were more proficient at different strategies. The authors conclude that, based on the research findings, they can define the areas where the university teachers can improve their strategies of motivational teaching.

Melnik (2014) states that academic motivation develops in an activity. Therefore, it is important to diversify studying activities that lead to more complicated creative tasks. The author scrutinizes different approaches of scientists (Zaniuk, 2002; Ilyin, 2000) to definition of 'motivation' and its connection with academic achievement and future professional identification. Melnik (2014) discusses the impact of games on academic motivation development in pre-service physical training teachers' education. To study the dynamics of students' motivation the author organized the research at Kirovograd Volodymyr Vynnychenko State Pedagogical University. The survey involved 64 fourth-year students. The diagnostic stage of the research revealed that $57 \%$ of respondents had strong academic motivation, $20 \%$ showed the medium level and $23 \%$ of students had low level of academic motivation. The author designed and implemented the set of games appropriate for the topic the students study. The findings at the final stage of the survey revealed the increase of students' academic motivation (high $-74 \%$, medium $-15 \%$, low-11\%). The dynamics of students' motivation proved the positive effect of using games in a studying process

To sum up:

- Very many aspects of learning and teaching motivation in secondary and higher education, as well as choosing the teacher's profession, are under study. 
- Motives and motivation level depend on historic period (social-economic environment) and culture, however, they are similar everywhere: intrinsic (interest in the field, love for intellectual work, self-development, sharing knowledge, etc.) and extrinsic (job security and employment prospects, administration / academic support, etc.).

- Motivated teachers and students may become demotivated, unless a support system exists.

- Motivation does not guarantee good teaching / learning, but lack of it definitely has a negative impact on the efficiency and quality of teaching and learning.

- Teacher alone cannot be responsible for student motivation - it depends very much on society, peers, family and the student him/herself. This is why awareness of this fact is very important and, correspondingly, cooperation of society and educationalists is essential.

- Motivation to study abroad is increasing nowadays with the growth of corresponding opportunities, and we can only welcome the internationalization of education, but it is important to motivate students to learn in their home countries as well (of course, on condition that the quality of teaching corresponds to international standards).

\section{References:}

Amrai, K., Motlagh, S.E., Zalani, H.A., \& Parhon, H. (2011).The relationship between academic motivation and academic achievement students. Procedia-Social and Behavioral Sciences, 15, 399-402.

Ates, H. \& Saylan, A. (2015) Investigation of pre-service science teachers' academic self-efficacy and academic motivation toward biology. International Journal of Higher Education, 4, 3, 90-103.

Atkinson, J. W. (1974). The main springs of achievement-oriented activity. In J. W. Atkinson \& J. O. Raynor (Eds.), Motivation and Achievement (p. 13-41). Washington, DC: Winston \& Sons.

Aydin, S. (2015). An Analysis of the Relationship between High School Students' Self-efficacy, Metacognitive Strategy Use and their Academic Motivation for Learning Biology. Journal of Education and Training Studies, 4, 2, 53-59

Bogoslovskaya, O. (2006). Motivatsia Polucheniya Vysshevo Obrazovanyya v Kontekste Vybora Professii. (Motivation of Obtaining Higher Education in the Context of Choosing a Profession). Vyssheye Obrazovaniye $v$ Rossii (Higher Education in Russia), 5, 44-47 
Bronfenbrenner, U. (2005). Making Human Beings Human: Bioecological Perspectives on Human Development. Thousand Oaks: Sage.

Bronfenbrenner, U. \& Morris, P. A. (1998). The ecology of developmental processes. In W. Damon \& R. M. Lerner (Eds.), Handbook of Child Psychology. Vol. 1. Theoretical Models of Human Development (5th ed., p. 993-1028). New York: John Wiley.

Bronfenbrenner, U. \& Morris, P. A. (2006). The bioecological model of human development. In W. Damon \& R. M. Lerner (Eds.), Handbook of Child Psychology: Vol. 1. Theoretical Models of Human Development (6th ed., p. 793-828). New York: John Wiley.

Cetin (2015). Academic motivation and approaches to learning in predicting college students' academic achievement: Findings from Turkish and US samples. Journal of College Teaching \& Learning, 12, 2, 141-150.

Cokley, K.O., Bernard, N., Cunningham, D., \& Motoike, J. (2001). A psychometric investigation of the academic motivation scale using a United States sample. Measurement and Evaluation in Counseling and Development, 34,109-119.

Deci, E. L., \& Ryan, R. M. (2002). An overview of self-determination theory: Organismic-dialectical perspective. In E. L. Deci \& R. M. Ryan (Eds.), Handbook of self-determination research (p. 3-33). Rochester, NY: The University of Rochester Press.

Diseth, A. (2002). The relationship between intelligence, approaches to learning and academic achievement. Scandinavian Journal of Educational Research, 46(2), 219-230.

Diseth, A. (2007). Students' evaluation of teaching, approaches to learning, and academic achievement. Scandinavian Journal of Educational Research, 51(2), 185-204.

Doghonadze, N. (2012 a). A survey on university lecturer job satisfaction. IBSU Journal of Education, 1 (1), 17-22.

Doghonadze, N. (2012 b). Undergraduate students' motivation. The fifth International Conference on Education and New Learning Technologies, Barcelona, Spain, 1-3 July, p. 4116-4128

Dörnyei, Z. (2001). Motivational Strategies in the Language Classroom. Cambridge: Cambridge University Press. 
Dubovitskaia, T. (2005). K probleme diagnostiki uchebnoi motivatsii. Voprosy Psikhologii, (1), 73-78 (To the problem of diagnosing the learning motivation. Issues of Psychology). (in Russian).

Ekinci, N. (2009). Learning approaches of university students. Education and Science, 34(151).

Elliott, J.G. \& Tudge, J. (2012). Multiple contexts, motivation and student engagement in the USA and Russia. European Journal of Psychology of Education, 27, 2, 161-175.

Fedorchuk, I. (2008). Materialy Vseukrainskoi naukovo-praktuchnoi konferentsii. In Suchasni tendentsii rozvytku ekonomiky, osvity ta nauky v konteksti evrointegratsii (pp. 212-213). Chernigiv: ChDIEU. (All-Ukrainian scientific and practical conference proceedings. In Modern tendencies of economics, education and science in the context of European integration). (in Ukrainian).

Fitzpatrick, S. (1999). Everyday Stalinism - Ordinary Life in Extraordinary Times: Soviet Russia in the 1930s. New York: Oxford University Press.

Giorgadze, L. Gogrichiani, M. \& Mdinaradze, N. (2014). Praqtikuli Kvleva: Qimiis Swavlis Motivacia SSIP Vladimer Komarovis Tbilisis Fizika-Matematikis \#199 Sajaro Skolis IX Klasshi (Practical Research: Motivation of learning Chemistry in LEPL Physics and Mathematics Vladimir Komarov Public School N199 IX 4 Grade). MA thesis. Tbilisi: Ilia State University.

Gogokhia, R. (2012). Utskhouri Enis Dauflebis Individualur-Typologiuri Taviseburebebis Kvleva (Research of Individual-Typological Peculiarities of Foreign Language Acquisition). PhD dissertation. Tbilisi: Ilia State University.

Goncharov, A. M. \& McGinlay, M.A. (2014) Tackling motivational issues of ESL learning at Russian technical universities. In Sovremennnyye Tendentsii v Prepodavanii Inostrannykh Yazykov v Neyazykovom Vuze (Contemporary Trends in Teaching Foreign Langauges in a Non-Linguistic Higher Education Institution). (p. 21-28). VIII International Scientific-Practical Conference. Krasnoyarsk: Siberian State Aerospace University named after academician M. F. Reshetnev.

Heikkila, A., \& ve Lonka, K. (2006). Studying in higher education: students' approaches to learning, selfregulation, and cognitive strategies. Studies in Higher Education, 31(1), 99-117.

Holmes, L. E. (2005). Schools and schooling under Stalin, 1931-1953. In B. Eklof, L. Holmes, \& V. Kaplan (Eds.), Educational Reform in Post-Soviet Russia (p. 56-101). London: Cass.

Ilyin, E. (2000). Motivatsia i momivy. (Motivation and Motives). St.Petersburg: Piter. 
Izmirli, S. \& Izmili, O. (2015). Factors motivating preservice teachers for online learning within the context of ARCS motivation model. Turkish Online Journal of Distance Education (TOJDE) 16, 2, 56-68.

Kolosovska, V. 2014). Otsiniuvannia sformovanosti motyvatsii maibutnikh uchyteliv pochatkovykh klasiv do ralizatsiiosobystisno orientovanoho pidkhodu u sportyvno-masovii roboti z uchniamy. Pedahohichnyi Protses: Teoria i Praktyka, (1), 62-66. (The evaluation of pre-service primary school teachers' motivation for the implementation of student-centered approach in practice. Pedagogical Process: Theory and Practice). (in Ukrainian).

Kvirikashvili, E. \& Gogochashvili, N. (2013). Kvlevaze dafudznebuli gadatskvetilebebis roli zogadsaganmanatleblo gatsesebulebebbis martvashi. (The role of research-based decision making in managing a general education institution).GESJ: Education Science and Psychology, 1 (27), 46-57.

Lavender, M.M. (2005). A Comparison of Academic Motivation of Academically Prepared and Academically Unprepared Community College Students (Unpublished doctoral dissertation). The Florida State University College of Education, Gainesville, FL, USA.

Marton, F. \& Saljo, R. (1976).On qualitative differences in learning - Outcome and process. British Journal of Educational Psychology, 46, 4-11.

Melnik, A.(2014). Pidvyshchennia motyvatsii maibutnikh uchyteliv fizychnoi kultury do navchalnoi diial nosti zasobamy ihrovykhtekhnolohii. Naukovi Zapysky KDPU. Seria: Pedahohichni Nauky, (131), 131-135. (Academic motivation of pre-service physical training teachers when using games in the studying process. Scientific Notes of KSPU. Series: Pedagogical Sciences). (in Ukrainian).

Moskalets, O., \& Ponomarenko, O. (2015). Rozvytok motyvatsii do vyvchennia inozemnykh mov u studentiv yak dzherelo profesiinoho rozvytku vykladacha. Visnyk Chernihivskoho Natsionalnoho Pedahohichnoho Universytetu im. T.H. Shevchenka. Seria: Pedahohichni Nauky, (131), 92-95. (Maintaining students' motivation for L2 acquisition as a source of teacher professional development. Bulletin of Chernihiv Taras Shevchenko National Pedagogical University. Series: Pedagogical Sciences). (in Ukrainian).

Necsoi, D.V. (2013). Motivation of Romanian students to study abroad. Journal Plus Education, XI, 2, 137140. 
Ozder, H., \& Motorcan, A. (2013). An analysis of teacher candidates' academic motivation levels with respect to several variables. British Journal of Arts and Social Sciences, 15(1), 42-53.

Peck, R. F., R. B. Fox, and Morston, P.T. (1977). Teacher Effects on Students' Achievement and SelfEsteem. Washington, DC: National Institute of Education

Robinson, N.M. (2003). Academic Motivation and its Relationship to Personality Variables and Achievement (unpublished doctoral dissertation). Southern Illinois University, Carbondale, IL, USA.

Semerci, C. \& Duman, B. (2013). Achievement Motivations of the Students Studying at Computer and Instructional Technologies Teaching Department. Mevlana International Journal of Education (MIJE), 3(1), 134-142.

Serbanescu, L. (2013). The relationship between the motivation to attend the teacher education programme and the acquisition of professional competences. The case of Romanian teachers. Procedia - Social and Behavioral Sciences, 76. 5th International Conference EDU-WORLD 2012 Education Facing Cotemporary World Issues. Elsevier, 770-774.

Shklyaev, A.E. (2013). Motivation of teaching job in an innovative university. In Vestnik Omskovo Universiteta (Newsletter of Omsk University), 4, 58-62.

Stewens, R., and White, W. (1987). Impact of teacher's morale on the classroom. Perceptual and Motor Skills, 65: 787-790.

Zaniuk, S. (2002). Psykholohia motyvatsii. Kyiv: Lybid. (Psychology of motivation. Kyiv: Lybid). (in Ukrainian). 